\title{
Calculation of Pile Capacity in Cohesionless Soil by CPT Considering Spatial Variability
}

\author{
Ahmet Can MERT ${ }^{* 1}$ ID $0000-0002-2483-1330$ \\ Gökhan YAZICI'1 ID 0000-0002-6719-9152
}

${ }^{1}$ İstanbul Kültür University, Faculty of Engineering, Department of Civil Engineering, İstanbul

Geliş tarihi: 15.06.2021 Kabul tarihi: 10.12.2021

Atıf şekli/ How to cite: MERT, A.C., YAZICI, G., (2021). Calculation of Pile Capacity in Cohesionless Soil by CPT Considering Spatial Variability. Çukurova Üniversitesi, Mühendislik Fakültesi Dergisi, 36(4), 1051-1059.

\begin{abstract}
The study aims to construct a framework for CPT based ultimate pile capacity calculation for cohesionless soils with random field theory. Cone tip resistance $\left(\mathrm{q}_{\mathrm{c}}\right)$ was taken as the spatially varying parameter with a constant mean and changing coefficients of variation. CPT profiles were simulated with random field generations, and the ultimate capacity of a single pile $\left(Q_{u}\right)$ was calculated with these simulations. The influence of spatial variation of $\mathrm{q}_{\mathrm{c}}$ on the variation of $\mathrm{Q}_{\mathrm{u}}$ was investigated. The proposed framework was finally verified by comparing the results of an actual CPT database and the simulated CPT profiles in the study. The results showed that the critical vertical scale of fluctuation for CPT-based pile capacity calculations was equal to one diameter of pile $\left(\mathrm{d}_{\mathrm{v}}=1 \mathrm{D}\right)$, and that the method effectively predicted the ultimate pile capacity through simulated CPT profiles with random field. The proposed method is especially recommended for cases where the uncertainty consideration is necessary, yet the site-specific data is limited. The study aims to contribute a simple framework to the methods of CPTbased pile capacity with unceratinty consideration. The propesed method aims to facilitate the pile design framework with limited available data.
\end{abstract}

Keywords: Cone penetration test, Ultimate pile capacity, Random fields, Spatial variability, Cohesionless soil

\section{Kohezyonsuz Zeminde CPT ile Kazık Kapasitesinin Boşluksal Değişkenlikle Hesabı}

$\ddot{\mathbf{O} z}$

Çalışma, kohezyonsuz zeminde CPT tabanlı kazık nihai taşıma kapasitesi hesabı için rastgele alan

\footnotetext{
* Sorumlu yazar (Corresponding author): Ahmet Can MERT, a.mert@iku.edu.tr
} 
teorisine dayalı bir yöntem oluşturmayı amaçlamaktadır. Koni uç direnci $\left(\mathrm{q}_{\mathrm{c}}\right)$, sabit alınan ortalama ve farklı değişme katsayısı (COV) değerleri ile boşluksal değişken olarak tanımlanmıştır. Rastgele alan ile CPT profilleri benzeştirilmiş ve tekil kazığın nihai kapasitesi $\left(\mathrm{Q}_{\mathrm{u}}\right)$ bu simule edilen profillerle hesaplanmıştır. qc'deki değişimin Qu değerlerine etkisi incelenmiştir. Önerilen yöntem son olarak, gerçek CPT veri tabanı ile ve simule CPT profilleri ile hesaplanan sonuçların karşılaştırılması ile doğrulanmıştır. Edinilen sonuçlar CPT tabanlı kazık kapasite hesaplarında, düşey dalgalanma ölçeğinin kritik değerinin bir kazık çapı kadar olduğunu ( $\left.\mathrm{d}_{v}=1 \mathrm{D}\right)$, ve yöntemin nihai kazık kapasitesini rastgele alan ile etkili bir şekilde tahmin ettiğini göstermiştir. Doğrulanan yöntem özellikle belirsizlik hesabı yapılması gerekli olan ancak yeterli sahaya özel verinin bulunmadığı durumlar için önerilmektedir. Çalışmanın literatüre, CPT tabanlı kazık kapasitesi yöntemlerine pratik bir çerçeve ile belirsizlik analizi eklemeyerek katkı sağlaması amaçlamaktadır. Ayrıca önerilen yöntemin, kısıtlı veri bulunması durumlarında kazık tasarımını kolaylaştırması hedeflenmiştir.

Keywords: Koni penetrasyon deneyi, Kazık nihai kapasitesi, Rastgele alanlar, Boşluksal değişkenlik, Kohezyonsuz zemin

\section{INTRODUCTION}

Piled foundations are one of the common solutions in geotechnical engineering. The bearing capacity of a single pile is the main parameter for analysis and design purposes. Even for design of a pile group, single pile capacity is required. Since the pile capacity is one of the main parameters for geotechnical design, estimation of the pile capacity should also include the uncertainty of soil conditions. These uncertainties may arise due to inherent soil variability, measurement errors and soil-structure interaction [1-3]. The use of in-situ test results to calculate pile capacity is a common approach since the data from the test covers most of the soil conditions includinf their uncertainties (i.e. initial stress conditions, water conditions). Among the in-situ methods, cone penetration test (CPT) based approach is one of the commonly used in engineering practice, because the CPT is a simple and an economical method to provide representative site information in field conditions [4,5]. Furthermore, the mechanics of the test and the pile capacity are analogous. Therefore, most of the CPT based pile capacity methods directly use the cone tip resistance $\left(\mathrm{q}_{\mathrm{c}}\right)$ data.

There have been many developments in the prediction of the ultimate pile capacity with CPT [6-8]. In addition to the methods proposed by researchers, many standards also include the CPT based pile capacity approach. For example, French Institute of Science and Technology for Transport, Development and Networks uses the so-called LCPC method proposed by Bustamante and Gianesselli [9]. The method uses the direct use of $\mathrm{q}_{\mathrm{c}}$ to predict the ultimate pile capacity. Although CPT based pile capacity methods offer high accuracy in estimation, the prediction of the ultimate capacity of single pile may still result in various errors due to the existence of transformation uncertainty, measurement errors and inherent soil variability $[10,11]$. Therefore, the estimation of ultimate capacity of monopiles in cohesionless soil (i.e., sand and silty sand) may fluctuate due to the spatial variation of soil material and uncertain geological conditions. Thus, these sources of uncertainties need to be considered for a better prediction of the ultimate pile capacity.

There are recent studies on the uncertainty in pile capacity [12], some of which consider the spatial variation of CPT or random field theory $[13,14]$. The present study aims to construct a framework for CPT based ultimate pile capacity calculation by considering spatial variability of cone tip resistance. The spatially variable $\mathrm{q}_{\mathrm{c}}$ was generated by using random field theory to calculate ultimate pile capacity of an example design. The influence of spatial variation of cone tip resistance on the 
variation of ultimate pile capacity was investigated. The proposed framework was finally verified by comparing the results of an actual CPT database and the generated random fields in the study. The proposed method is especially recommended for cases where the uncertainty consideration is necessary, yet the site-specific data is limited. The study aims to contribute a simple framework to the methods of CPT-based pile capacity with unceratinty consideration. The propesed method aims to facilitate the pile design framework with limited available data.

\section{CPT BASED ULTIMATE PILE CAPACITY}

One of the most used CPT based pile capacity method in geotechnical engineering practice was employed in this study. The method is called the French method (or LCPC method) after the approach became a standard method in French Road and Transportation Research Laboratory (Laboratoire Central des Ponts et Chausees) [9]. The LCPC method determines the maximum pressure at pile base $\mathrm{q}_{\mathrm{p}}$ as follows (Equation 1):

$q_{p}=\alpha_{p} \cdot q_{c, e q} \#$

where $\alpha_{p}$ pile base coefficient, $\mathrm{q}_{\mathrm{c}}$, eq equivalent average cone tip resistance which is calculated by averaging $\mathrm{q}_{\mathrm{c}}$ values over a zone ranging from 1.5D below the pile tip to $1.5 \mathrm{D}$ above the pile tip ( $\mathrm{D}$ is the pile diameter).

The maximum shaft friction $\mathrm{q}_{\mathrm{s}}$ is given by Equation 2:

$q_{s}=\alpha_{s} \cdot q_{c, z} \#$

where $\alpha_{\mathrm{s}}$ shaft friction coefficient $\mathrm{q}_{\mathrm{c}, \mathrm{z}}$ tip resistance along pile shaft Pile base and shaft friction coefficients are taken from the chart (Table 1 and 2). Base pressure and shaft friction are used to calculate the ultimate pile bearing capacity $\mathrm{Q}_{\mathrm{u}}$ for the given pile length (L) and pile diameter (Equation 3):
$Q_{u}=Q_{s}+Q_{p}=\pi D L q_{s}+\frac{\pi D^{2}}{4} q_{p} \#$

The range of cohesionless soils were employed for the bored pile type in Table 1 and 2, and all the pile capacity calculation in the study were performed by using equation 3 .

Table 1. Pile base coefficients

\begin{tabular}{|c|c|c|}
\hline Soil Type & $\mathrm{q}_{\mathrm{c}}(\mathrm{MPa})$ & $\mathrm{a}_{\mathrm{p}}$ \\
\hline \multirow{3}{*}{ Clay } & $\mathrm{q}_{\mathrm{c}} \leq 1$ & 0.04 \\
\cline { 2 - 3 } & $1<\mathrm{q}_{\mathrm{c}}<5$ & 0.35 \\
\cline { 2 - 3 } & $5 \leq \mathrm{q}_{\mathrm{c}}$ & 0.45 \\
\hline \multirow{3}{*}{ Sand } & $\mathrm{q}_{\mathrm{c}}<12$ & 0.40 \\
\cline { 2 - 3 } & $12 \leq \mathrm{q}_{\mathrm{c}}$ & 0.30 \\
\hline
\end{tabular}

Shaft friction has a limit and the minimum value from the chart should be used.

Table 2. Shaft friction coefficient

\begin{tabular}{|c|c|c|c|}
\hline $\begin{array}{c}\text { Soil } \\
\text { Type }\end{array}$ & $\mathrm{q}_{\mathrm{c}}(\mathrm{MPa})$ & $\mathrm{a}_{\mathrm{s}}$ & $\begin{array}{c}\text { Max. Shaft } \\
\text { resistance }(\mathrm{kPa})\end{array}$ \\
\hline Clay & $\mathrm{q}_{\mathrm{c}} \leq 1$ & 0.033 & 15 \\
\hline & $1<\mathrm{q}_{\mathrm{c}}<5$ & 0.025 & 35 \\
\hline Sand & $5 \leq \mathrm{q}_{\mathrm{c}}$ & 0.017 & 35 \\
\hline & $5<\mathrm{q}_{\mathrm{c}}<5$ & 0.010 & 0.010 \\
\hline & $12 \leq \mathrm{q}_{\mathrm{c}}$ & 0.007 & 80 \\
\hline
\end{tabular}

\section{MECHANICAL PROPERTIES AND MODELLING}

\subsection{Random Field Theory}

Spatial variation of the mechanical properties of soil significantly complicates the reliability assessment. In this study, random field theory was 
utilized to carry out the reliability assessment of CPT based ultimate pile capacity calculation. The theory, which accounts for the variation of any random variable in space, is an efficient for uncertainty in one, two or three-dimensional spatial variation of mechanical properties [15]. The proposed method requires definition of random field for spatially varying parameter by a correlation function $r(t)$. The parameter $t$ is the distance between random variables in the field. The correlation function also includes the main parameter for random field, which is called scale of fluctuation (d), and is given for an exponential Markovian type as Equation 4:

$$
\rho(\tau)=\exp \left(-\frac{2|\tau|}{\delta}\right)
$$

The present study modelled the cone tip resistance $\left(\mathrm{q}_{\mathrm{c}}\right)$ as a Gaussian random field with exponential correlation given in Equation 4.

\subsection{Spatial Variability of CPT}

Cone tip resistance $\left(\mathrm{q}_{\mathrm{c}}\right)$ was defined as a spatially varying parameter for ultimate pile capacity calculation. The variation was modelled by a onedimensional Gaussian random field along the depth. Mean (m) and coefficient of variation $(\mathrm{COV})$ are required for the definition of the field along with scale of fluctuation (d) which is the main parameter. An extensive study reported that the range of $\mathrm{q}_{\mathrm{c}}$ in cohesionless soils varied between 0.4-29.2 MPa with COV of 10-80\%. They also suggested that the vertical scale of fluctuation $\left(d_{v}\right)$ for $q_{c}$ varied between 0.1 to 2.2 meters [1]. All the values for variability have been employed within these limits.

\subsection{Pile Geometry and Random Field Generation}

A single pile was selected with $8 \mathrm{~m}$ in length (L) and $0.6 \mathrm{~m}$ in diameter (D). All the ultimate pile capacity calculations were performed by using the given geometry.

The variability of $\mathrm{q}_{\mathrm{c}}$ can be represented as a lognormal random field described by mean $\left(\mathrm{m}_{\mathrm{qc}}\right)$, $\mathrm{COV}_{\mathrm{qc}}$, and vertical scale of fluctuation [15-17]. Lognormal distribution prevents the negative values and has been shown to be effective in simulating spatial variability of $\mathrm{q}_{\mathrm{c}}[1,18]$. Hence, $\mathrm{m}_{\mathrm{qc}}$ was taken as $15 \mathrm{MPa}$ and the parameter was assumed to be lognormally distributed. $\mathrm{COV}_{\mathrm{qc}}$ was selected 10, 20, 40 and $80 \%$ which conformed the suggested range. Vertical scale of fluctuation was taken as the multiples of the pile diameter; $0.5 \mathrm{D}$, $1 \mathrm{D}, 2 \mathrm{D}$ and 4D which varied between 0.3 to $2.4 \mathrm{~m}$. One-dimensional random field of $\mathrm{q}_{\mathrm{c}}$ was generated by MATLAB code with the given mean, COVs and $d_{v}$. The realizations were generated for every $2 \mathrm{~cm}$ along the depth of $15 \mathrm{~m}$ which is the common sampling rate of CPT. For each $d_{v}$ value, 4 different random field were generated for each $\mathrm{COV}_{\mathrm{qc}}$. Each generation contained 1000 realizations, which made 4000 realizations for each $d_{v}$ and total 16000 realizations. Figure 1 shows some of the representative realizations of the generated CPT profiles by random field for each scale of fluctuation.

\subsection{Methodology}

The study aims to present the effect of $\mathrm{q}_{\mathrm{c}}$ variation in ultimate pile capacity $\left(Q_{u}\right)$. Initially, spatial variation of $\mathrm{q}_{\mathrm{c}}$ was defined as random field by MATLAB code. Each realization represented an arbitrary CPT profile for the given statistics. Therefore, all the generated profiles were employed to calculate ultimate pile capacity by LCPC method. Output capacities were recorded to obtain probability density functions (PDF). Finally, statistical information of the output PDFs was presented and the effect of $\mathrm{q}_{\mathrm{c}}$ variation on the ultimate pile capacity was investigated. Figure 2 presents the main framework of the proposed method. 

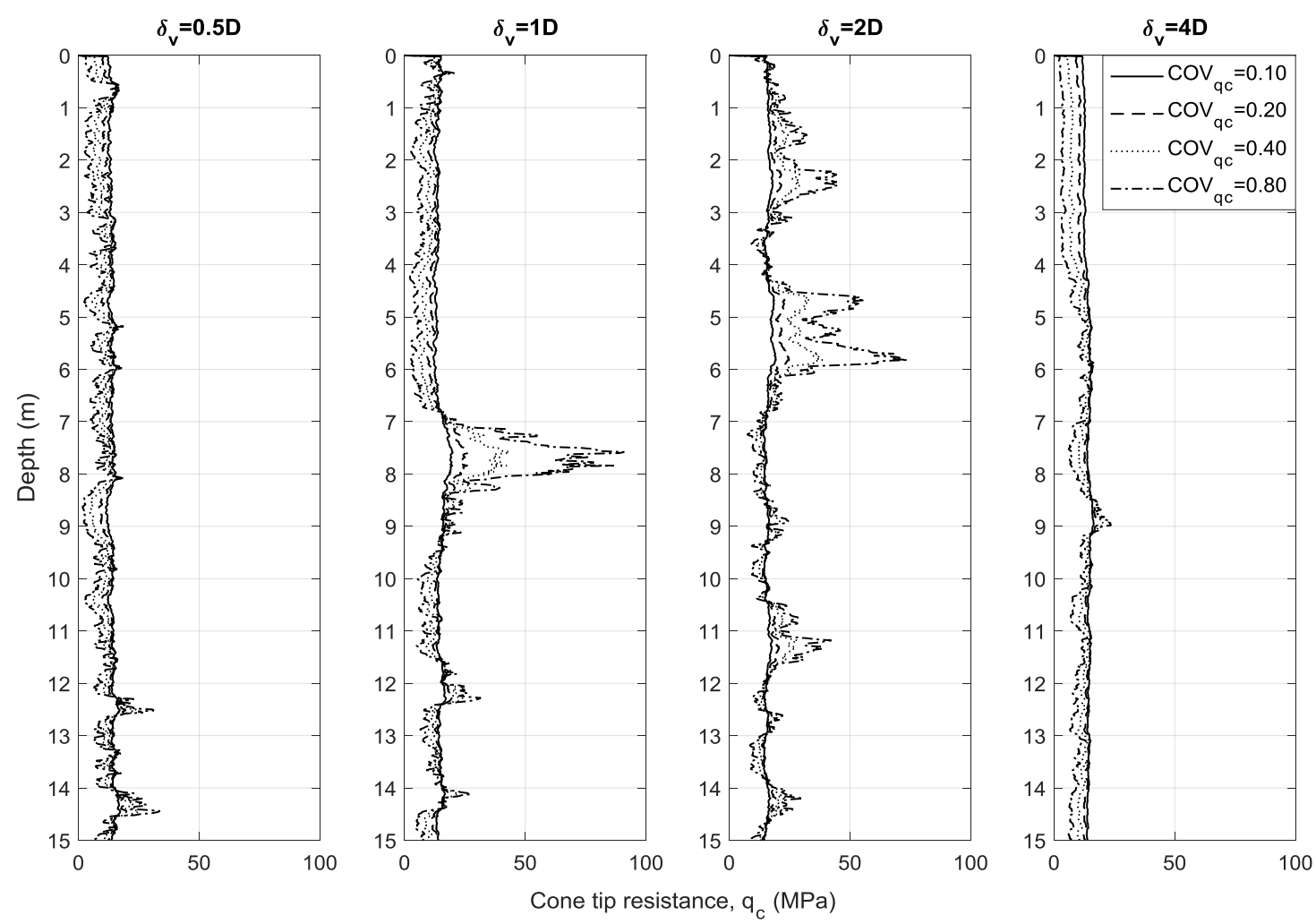

Figure 1. Representation of generated CPT profiles

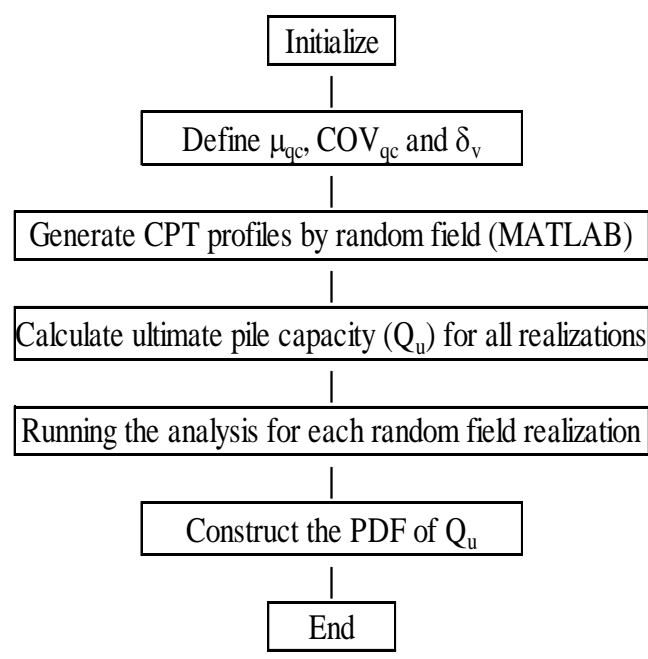

Figure 2. Flowchart of the proposed method

\section{VERIFICATION PROPOSED METHOD}

The method proposed in the present study can be used for the cases when there is known uncertainty measures in a region with limited data available. The statistical parameters from the site can be assigned into the first step of the flow chart in figure 2, and the random field of CPT profiles can subsequently be generated in order to perform reliability assessment of the ultimate pile capacity. A sample CPT database from ISSMGE technical committee TC304 for engineering practice of risk assessment and management was employed to verify the proposed method.

(https://www.issmge.org/committees/technicalcommittees/impact-on-society/risk). The database has $25 \mathrm{CPT}$ profiles with total depths of 13 to $13.5 \mathrm{~m}$. The test site is located in Hollwood, South 
Carolina, USA and beach sand and silty sand are predominant in the region. It has been reported that $\mathrm{d}_{\mathrm{v}}$ for the database is approximately $0.5 \mathrm{~m}$ [19]. Mean $\mathrm{q}_{\mathrm{cs}}$ are varying between 4.07 to 6.23 $\mathrm{MPa}$ with $\mathrm{COV}_{\mathrm{qc}}=50.2-107.5 \%$. The statistical information was employed to generate CPT profiles by random field as described in the proposed methodology. CPT profiles from the database and the simulated profiles for the given

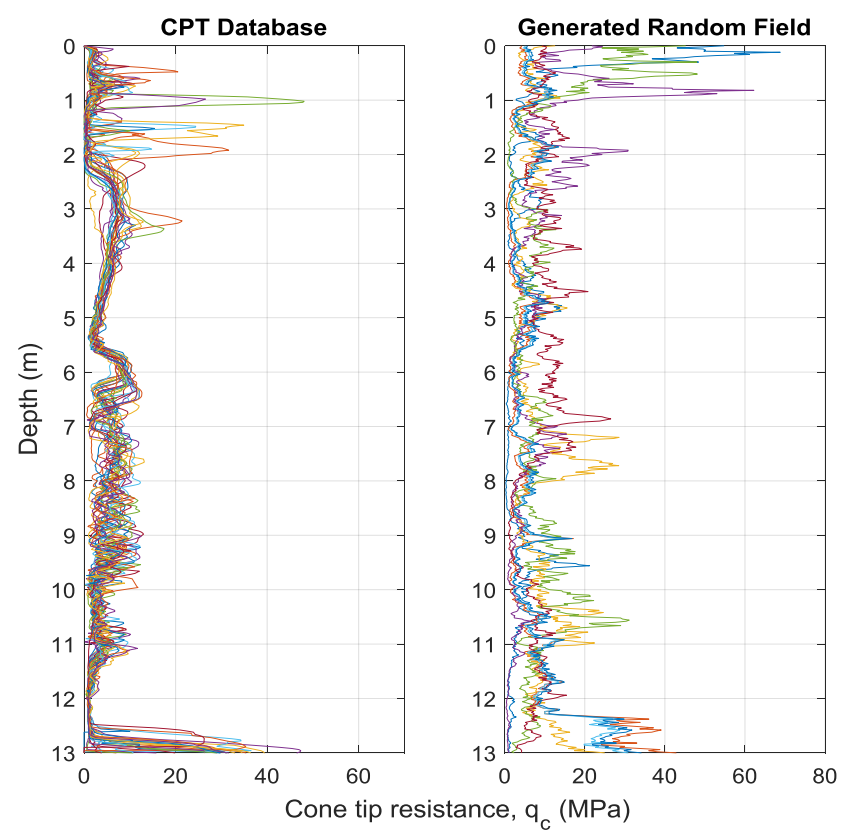

Figure 3. Actual and simulated CPT profiles of the database

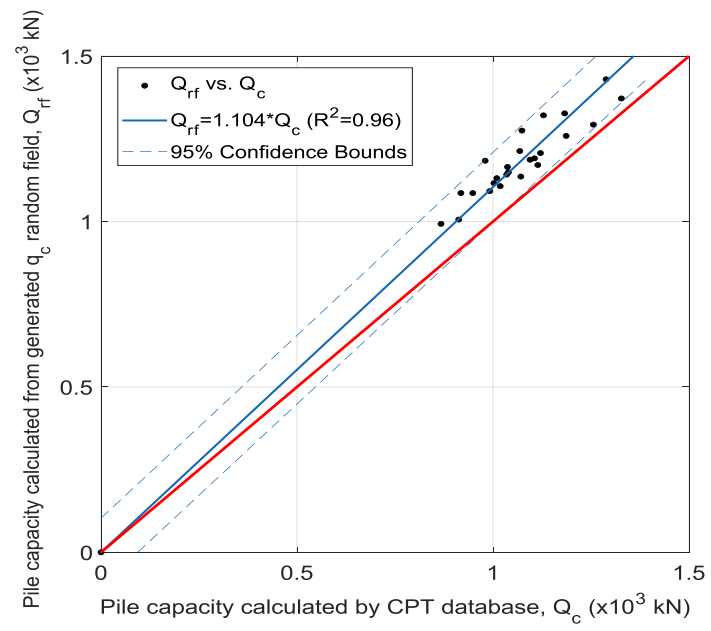

Figure 4. Ultimate pile capacity comparison statistical parameters were compared (Figure 3). The ultimate pile capacity were calculated by LCPC method by using both CPT database and simulated data. Ultimate capacities calculated from database $\left(\mathrm{Q}_{\mathrm{c}}\right)$ and random field generation $\left(\mathrm{Q}_{\mathrm{rf}}\right)$ were compared, and the regression of the results showed that the proposed method gave a reliable prediction of the pile response with $R^{2}=0.96$ (Figure 4).

$\mathrm{Q}_{\mathrm{rf}}$ slightly overestimated the ultimate pile capacity comparing to the actual results, but the values were still within the $95 \%$ confidence bounds, which validated the proposed method. The further analyses were conducted by using the validated framework.

\section{RESULTS}

Analyses performed with the generated random fields for the selected $\mathrm{m}_{\mathrm{qc}}, \mathrm{COV}_{\mathrm{qc}}$ and $\mathrm{d}_{\mathrm{v}}$. The effect of variability and vertical scale of fluctuation of $\mathrm{q}_{c}$ on the variation of $\mathrm{Q}_{\mathrm{u}}$ was investigated. Varitation of output PDFs were represented by $\mathrm{COV}_{\mathrm{Qu}}$, and the values were plotted against $\mathrm{COV}_{\mathrm{qc}}$ and $\mathrm{d}_{\mathrm{v}}$ (Figure 5 and 6). 


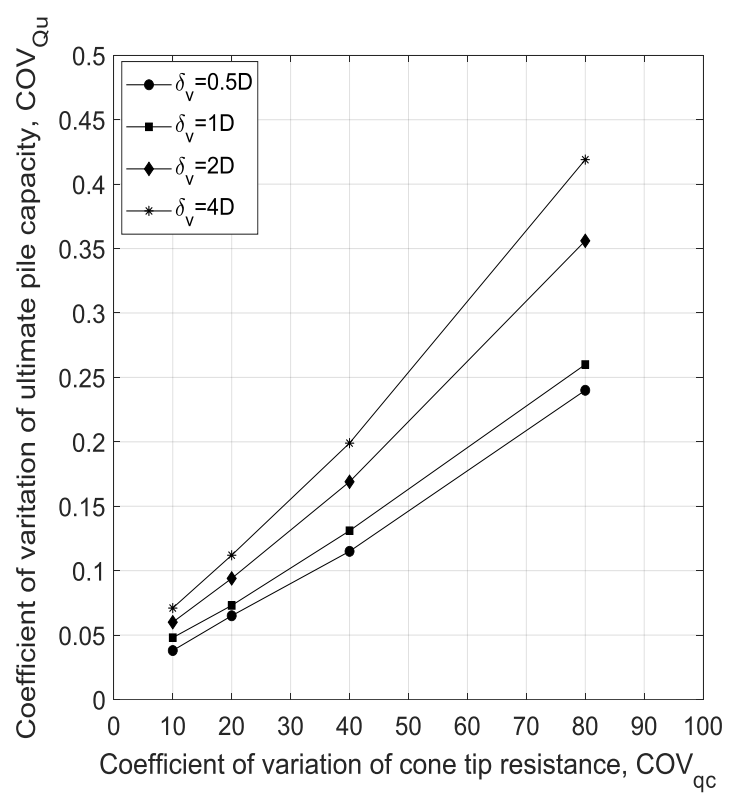

Figure 5. $\mathrm{COV}_{\mathrm{Qu}}$ versus $\mathrm{COV}_{\mathrm{qc}}$ plot

It was shown that variation of $\mathrm{Q}_{\mathrm{u}}$ is increasing as the variation of $\mathrm{q}_{\mathrm{c}}$ increases which suggests the consideration of uncertainty.

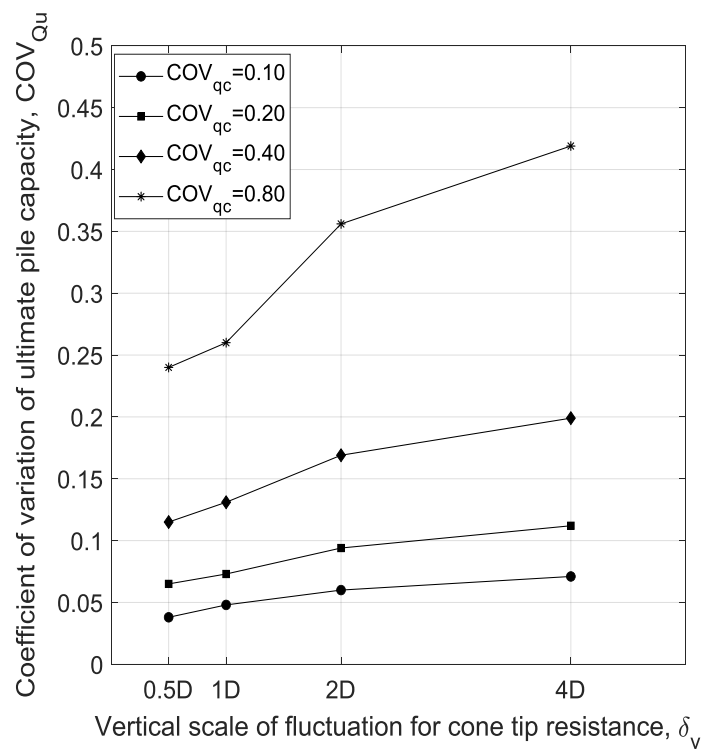

Figure 6. The influence of $d_{v}$ on $\operatorname{COV}_{\mathrm{Qu}}$

Results showed that the pile capacity considerably varied with high variation of tip resistance confirming the significance of uncertainty assessment.

There was a slight increase for $\mathrm{COV}_{\mathrm{Qu}}$ for increasing scale of fluctuation, especially for $\mathrm{COV}_{\mathrm{qc}}<40 \%$ since the variation of tip resistance became tolerable for pile capacity beyond that limit. Increase in $d_{v}$ provides higher possibility to assign low properties over a larger region, which results in the higher changes of the output variations. Therefore, the critical value of $\mathrm{d}_{\mathrm{v}}$ should be considered for the specific desing purposes. The influence of change in input parameter on the mean of ultimate pile capacity $\left(\mathrm{m}_{\mathrm{Qu}}\right)$ was also investigated. Figure 7 and 8 depicts the effects of $\mathrm{COV}_{\mathrm{qc}}$ and $\mathrm{d}_{\mathrm{v}}$ on $\mathrm{COV}_{\mathrm{Qu}}$, respectively.

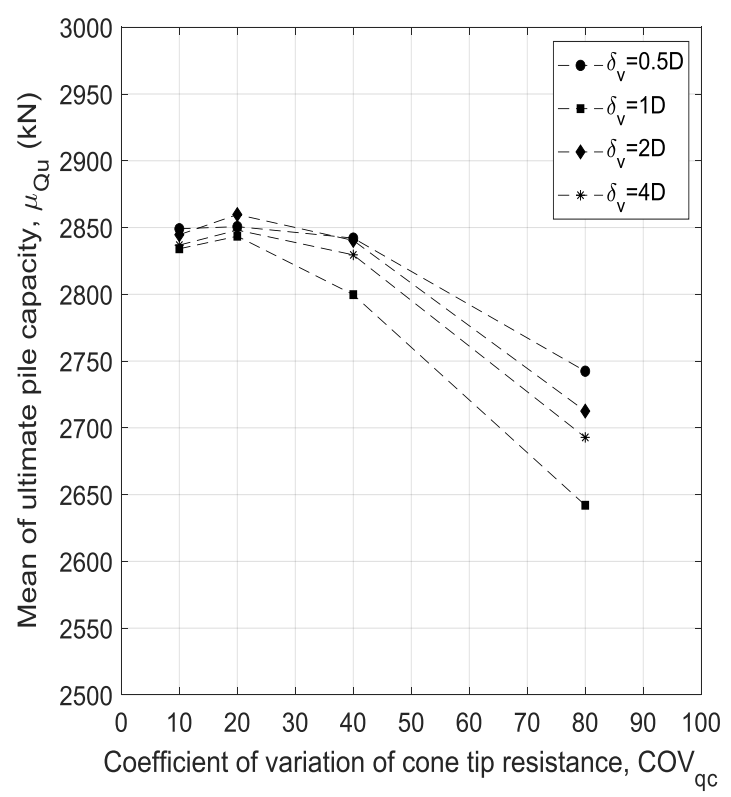

Figure 7. Effect of $\mathrm{COV}_{\mathrm{qc}}$ on $\mu_{\mathrm{Qu}}$

There was obvious decrease in $\mathrm{m}_{\mathrm{Qu}}$ for increasing $\mathrm{COV}_{\mathrm{qc}}$, particularly after $20 \%$ and greater. It can be expained as the effect of $\mathrm{COV}_{\mathrm{qc}}$ in the shape of output distribution of $\mathrm{Q}_{\mathrm{u}}$. After $20 \%$ change the variation became dominant and the mean value of $\mathrm{Q}_{\mathrm{u}}$ decreased. Mean of pile capacity was slightly increasing for $\mathrm{d}_{\mathrm{v}}$ which is equal to the pile diameter. 


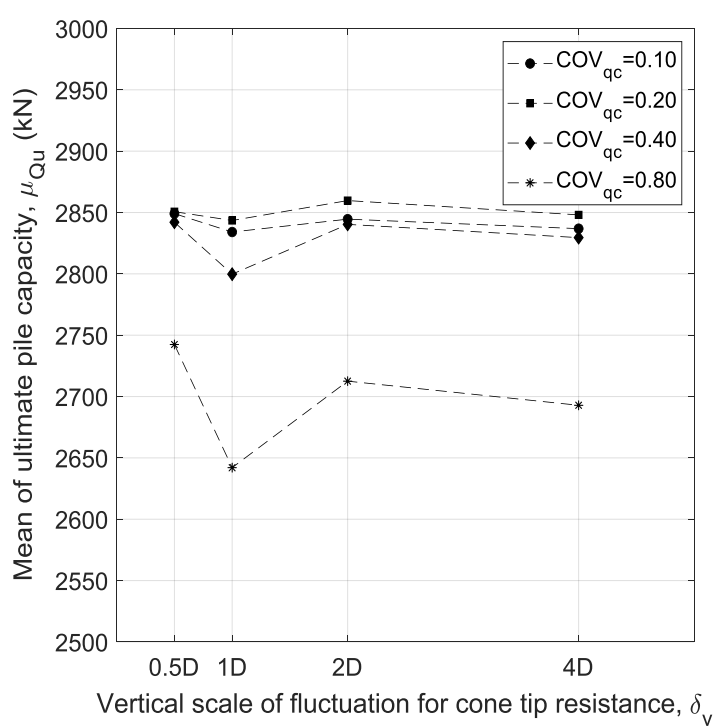

Figure 8. $d_{v}$ versus $m_{Q u}$ plot

It was clearly seen from figure 8 that the mean values were significantly varying for $\mathrm{COV}_{\mathrm{qc}}=$ $80 \%$. There was a slight variation of mean values for changing scale of fluctuations except for $\mathrm{d}_{\mathrm{v}}=1 \mathrm{D}$ case, which suggested that the critical value of the vertical scale of fluctuation for pile capacity problems were one diameter. The results also showed the necessity of reliability assessment for pile design and analysis even for in-situ based methods.

\section{CONCLUSIONS AND RECOMMENDATIONS}

The results of the study showed the necessity of spatial variability of CPT for reliability assessment of single pile in cohesionless soil. The change in $\mathrm{COV}_{\mathrm{qc}}$ and $\mathrm{d}_{\mathrm{v}}$ obviously affected the variation of $\mathrm{Q}_{\mathrm{u}}$. It can be concluded that the pile capacity considerably varied with high variation of tip resistance confirming the significance of uncertainty assessment. Mean value of ultimate pile capacity was sligthly influenced by $d_{v}$. However, the essential finding must be emphasized that the critical vertical scale of fluctuation for CPT-based pile capacity calculations was equal to one diameter of pile $\left(d_{v}=1 D\right)$. Therefore, the consideration of critical value of $d_{v}$ for the specific pile desing purposes is recommended. The proposed method effectively predicted the ultimate pile capacity by simulated CPT profiles by random field. The method offers a reliability assessment opportunity for in-situ based pile design and analysis when the uncertainty needs to be taken into consideration with limited available data. The propesed method efficiently facilitated the pile design framework with limited in-situ data.

\section{REFERENCES}

1. Phoon, K.K., Kulhawy, F.H., 1999. Characterization of Geotechnical Variability. Canadian Geotechnical Journal, 36(4), 612-624.

2. Ghorbani, B., Sadrossadat, E., Bazaz, J.B., Oskooei, P.R., 2018. Numerical ANFIS-based Formulation for Prediction of the Ultimate Axial Load Bearing Capacity of Piles Through CPT Data. Journal of Geotechnical and Geoenvironmental Engineering, 36(4), 2057-2076.

3. Padmini, D., Ilamparuthi, K., Sudheer, K.P., 2007. Ultimate Bearing Capacity Prediction of Shallow Foundations on Cohesionless Soils Using Neurofuzzy Models. Computers and Geotechnics, 35(1), 33-46.

4. Valikhah, F., Eslami, A., Veiskarami, M., 2019. Load-displacement Behavior of Driven Piles in Sand Using CPT-based Stress and Strain Fields. International Journal of Civil Engineering, 17(12), 1879-1893.

5. Wang, C.H., Osorio-Murillo, C.A., Zhu, H.H., Rubin, Y., 2017. Bayesian Approach Calibrating Transformation Model from Spatially Varied CPT Data to Regular Geotechnical Parameter. Computers and Geotechnics, 85, 262-273.

6. Tumay, M.T., Fakhroo, M., 1981. Pile Capacity in Soft Clays Using Electric QCPT Data. In: Proceedings of a Conference on Cone Penetration Testing and Experience. (St Louis), 434-455.

7. Robertson, P.K., Campanella, R.G., Davies, M.G., Sy, A., 1988. Axial Capacity of Driven Piles in Detail Soils Using CPT. Proceeding of 
International Symposium on Penetration Testing, ISOPT-1, Orlando. Balkema Pub., Rotterdam, 2, 919-928.

8. Eslami, A., Fellenius, B.H., 1997. Pile Capacity by Direct CPT and CPTu Methods Applied to 102 Case Histories. Canadian Geotechnical Journal, 34(6), 886-994.

9. Bustamante, M., Gianeselli L., 1982. Pile Bearing Capacity Prediction by Means of Static Penetrometer CPT. Proceedings of $2^{\text {nd }}$ European Symposium on Penetration Testing, Amsterdam, 493-500.

10. Phoon, K.K., Kulhawy, F.H., 1999. Evaluation of Geotechnical Property Variability. Canadian Geotechnical Journal, 36(4), 625-639.

11. Beck, J.L., Au, S.K., 2002. Bayesian Updating of Structural Models and Reliability Using Markov Chain Monte Carlo Simulation. Journal of Engineering Mechanics, 128(4), 380-391.

12. Xu, D., Liu, Z., Chen, B., Xu, X., 2020. Bearing Capacity Analysis of Offshore Pipe Piles with CPTs by Considering Uncertainty. Computers and Geotechnics, 126, 103731.

13. Baker, J.W., Faber, M.H., 2008. Liquefaction Risk Assessment Using Geostatistics to Account for Soil Spatial Variability. Journal of Geotechnical and Geoenvironmental Engineering, 134, 14-23.

14. Cai, Y., Bransby, F., Gaudin, C., Uzielli, M., 2021. A Framework for the Design of Vertically Loaded Piles in Spatially Variable Soil. Computers and Geotechnics, 134, 104140.

15. Vanmarcke, E., 2010. Random Fields: Analysis and Synthesis. World Scientific, New Jersey, USA.

16. Fenton, G.A., Griffiths, D.V., 2008. Risk Assessment in Geotechnical Engineering. Wiley, New York, USA.

17. Cai, Y., Li, J., Li, X., Li, D., Zhang, L., 2019. Estimating Soil Resistance at Unsampled Locations Based on Limited CPT Data. Bulletin of Engineering Geology and the Environment, 78(5), 3637-3648.

18. Uzielli, M., Lacasse, S., Nadim, F., Phoon, K.K., 2007. Soil Variability Analysis for Geotechnical Practice. In: Proceedings of the $2^{\text {nd }}$ International Workshop on Characterisation and Engineering Properties of Natural Soils (eds Tan, T.S., Phoon, K.K., Hight D.W., Leroueil, S.,), The Netherlands: Taylor and Francis, Singapore, 1653-1752.

19. Bong, T., Stuedlein, A.W., 2017. Spatial Variability of CPT Parameters and Silty Fines in Liquefiable Beach Sands. Journal of Geotechnical and Geoenvironmental Engineering, 143(12), 04017093. 
